\title{
Censorship in High School Libraries in Israel: An Analysis of School Sectorial Affiliation Effect
}

\author{
MOSHE YITZHAKI \\ Department of Information Studies, \\ Bar-Ilan University, \\ Ramat - Gan, Israel \\ yitzhm@mail.biu.ac.il
}

\begin{abstract}
Although school libraries have existed in Israel for several decades, some of them dating back to the 50's, the issue of censorship has not been studied. The objective of this full-blown study was to empirically assess the current state of censorship in a large sample of high school libraries in Israel, following an exploratory study.

The sample comprised 98 high schools, from both the 'religious' and 'nonreligious' sectors. The main research tool was a two-parts questionnaire, designed to be filled out during the researcher's visit to the library. Most librarians reported that some form of control, restriction or supervision was, always or very often, applied to books being added to the collection, usually by the head librarian, and/or the school principal. None of the libraries had any kind of written document, or even an unwritten statement specifying instructions or policy regarding book selection and acquisition. The librarians never mentioned any external pressure to censor the existing collection or books to be acquired, and clearly the censorship was strictly internal, initiated by the librarians themselves and other members of the school staff. In both sectors there was wide agreement on banning titles which included violence, hard pornography, racism and drugs, but there were considerable differences regarding 'soft' pornography, sexual permissiveness and books degrading the Jewish religion or its values, principles or commands. A comparison of four lists of specific titles against the catalogs showed that the non-religious sector libraries owned three times the percentage from the first list (explicit violence and sex), but only less than half the percentage from the fourth list ('Judaism'), compared to the religious sector. Interestingly, the religious group had lower percentages of both the 'right-wing' and 'left-wing' lists, due to its smaller collections, but had relatively more from the 'right-wing' list than the 'left-wing' one, while in the libraries of the non-religious sector the situation was reversed.
\end{abstract}

\section{BACKGROUND}

The issue of censorship in school libraries has long concerned researchers and practitioners in the field and is well documented in literature. A literature survey reveals dozens of opinion articles as well as research papers reporting empirical field studies, 
especially in the US, which attempt to determine the extent and objects of censorship and its underlying factors.

Discussing research on censorship attempts in school libraries, Hansen (1987) and Martorelli (1982) pointed out the increase in school censorship and the often unclear use of the term. Hopkins reviewed (1989) the literature to identify factors influencing the results of censorship attempts regarding school library materials and developed (1993) a conceptual model encompassing the various factors involved, especially in secondary school settings. Woods (1989) published an annotated bibliography covering more than a decade and Foerstel, in his 'reference guide' book Banned in the USA (1994), focused on book-banning in public schools and libraries, and pointed out that the major grounds for censorship were sex, profanity and religion, which were often intertwined to cover a broad range of "unacceptable" attitudes or ideas. Symons and Harmon's Protecting the Right to Read (1995) discusses the issue of intellectual freedom in libraries and offers guidelines for ensuring the right to read.

It is worth noting that challenges to school library materials came not only from 'external' sources e.g. parents, citizens' organizations etc. - (Martorelli, 1982) but also from the school community itself, for example principals (Hopkins, 1995), librarians (Serebnik, 1982), media specialists (Woods \& Salvatore, 1981) and other school personnel at all levels (Burress, 1967). In a recent article, Schrader (1996) explains why challenges to school library materials are unavoidable and points out that the method of 'censorproofing' by title, author etc. is a wrong substitute for professional responsibility.

\section{Purpose of the Study and the Research Questions}

Although school libraries have existed in Israel for several decades, some of them dating back to the 50's, the issue of censorship has not been studied. An exploratory study of 25 high school libraries in Israel was carried out in 1997 by the present author and reported in the IASL 1998 conference.

The objective of the present study was to empirically assess the current state of censorship in a large sample of high school libraries in the country, through a large scale study, based on the lessons learned from our exploratory study. The study was limited to the Jewish sector, since the Arab sector's educational system differs considerably in many aspects from the Jewish one and thus deserves an entirely separate study.

The specific research questions were:

1. Have high school librarians encountered censorship attempts and by whom?

2. Do they themselves censor their libraries and against what type of materials/ topics?

3. Is the application of self-censorship associated with the sectorial affiliation of school? 


\section{METHODOLOGY}

The Jewish educational system in Israel is traditionally divided into three statesupported sectors: (1) the 'non-religious' sector ('Mamlahti') which encompasses about $75 \%$ of the high schools (including junior high), (2) the 'religious' sector ('Mamlahti Dati') affiliated with the modern-orthodox movement, encompassing about $18 \%$ and, (3) the 'Haredi' sector (7\%) affiliated with the ultra-orthodox movement and consisting of three main factions: Lithuanian, Hassidic and Sephardic. Since one of our main hypotheses was that school sectorial affiliation is a major factor affecting the extent of censorship, the sample was designed to include similar proportions from both the 'non-religious' sector and the 'religious' one. Schools belonging to the 'Hareidi' sector, known to apply strict censorship, were excluded from the sample in light of a preliminary study, showing them to differ considerably and indicating the need for an entirely different type of questionnaire.

The current sample, combined with the exploratory one, comprised 98 high schools located in various regions of the country, from Haifa in the north to Beer-Sheba in the south, each having a library of at least 500 titles or 1000 volumes. These 98 high schools were randomly chosen from a population of about 500 high schools that existed in the nonreligious and religious sectors at the end of 1997. The random stratified selection of the sample increased the chances of including different types of schools from various socioeconomic sectors, in urban and non-urban areas. Since libraries in junior-high schools were found to differ in various aspects from those in upper schools, it was decided to concentrate on the latter and to include only a small number of junior-high libraries as a control group for comparison purposes. Junior-high schools are therefore underrepresented in the sample. The rate of response was relatively high (87\%) due to the personal interview method used, with each school library personally visited by the interviewer. An official letter from the Ministry of Education approving the conduction of the study was very helpful in obtaining the school principal's permission and the school librarians interviewed were usually very co-operative.

The main research tool was a lengthy two-part questionnaire, designed to be filled out during the researcher's visit to the library. The first part, necessitating a personal interview with the librarian, included 13 closed questions regarding the school, its library size and librarian's education. Three additional questions referred in general to the extent and source of censorship applied. The working definition of 'censorship' in this study was: "any type of supervision, control or restriction applied when adding new book titles to the library collection".

The last question of this part included a list of 22 controversial topics (violence, pornography, racism, drugs, etc.) from which the librarian was asked to indicate those which she or he "prefers in principle to exclude from the collection". Following Serebnik's study (1982), the second part of the questionnaire consisted of four separate lists of 25 to 30 book titles, to be checked against the library's catalog, in order to verify whether it carries them. The four lists included original and translated fiction books and original non-fiction ones, in Hebrew, with the following features, each of which was typical to one of the lists: (1) violence, explicit sex relations, etc. (2) right-wing orientation (see Appendix), (3) left-wing orientation (see Appendix), (4) Judaism, Jewish classics, repentance, etc. Most titles were 
considered controversial to various degrees and were obtainec using the Delphi method from among teachers and librarians studying in the Bar-Ilan Department of Information and Library Studies.

\section{FINDINGS AND DISCUSSION}

\section{Demographic features}

Affiliation: the final sample included 77 high schools affiliated with the non-religious sector $(78.6 \%)$ and 21 high schools affiliated with the religious sector $(21.4 \%)$ resembling the nation-wide relative proportions of both sectors.

\section{Table 1}

\section{Geographical Location of Schools Included in the Sample}

\begin{tabular}{lccc}
\hline Type of Settlement & Non-religious Sector & Religious Sector & Total Sample \\
\hline $\begin{array}{l}\text { Three Major Cities } \\
\text { (Jerusalem, Tel- }\end{array}$ & 9.1 & 14.3 & 10.2 \\
$\begin{array}{l}\text { Aviv, Haifa) } \\
\begin{array}{l}\text { Other Large Cities } \\
(100,000-200,000)\end{array}\end{array}$ & 33.8 & 38.1 & 34.7 \\
$\begin{array}{l}\text { Middle-size Towns } \\
(50,000-100,000)\end{array}$ & 24.7 & 19.0 & 23.5 \\
$\begin{array}{l}\text { Small Towns } \\
(20,000-50,000)\end{array}$ & 15.6 & 14.3 & 15.3 \\
$\begin{array}{l}\text { Rural Settlements } \\
\text { Total No. of Schools }\end{array}$ & $100 \%$ & 14.3 & 16.3 \\
\hline
\end{tabular}

As seen in Table 1,10\% of the schools were located in the three major Israeli cities (including the capital, Jerusalem) more than a third (35\%) were located in other large cities, mostly in the coastal part of the country, the metropolitan area, known as Greater Tel-Aviv or the 'Dan Block' ('Gush Dan'). Another $23.5 \%$ were in middle-size towns and the rest $(31.6 \%)$ were divided almost evenly between small towns and rural settlements. Generally speaking, this breakdown resembled that of the Israeli population, which is highly urbanized and heavily concentrated in the coastal area. As for the subsamples, the religious sector had relatively more schools located in other large cities, but when middle-size towns are added the proportions are very similar (about $60 \%$ ).

Regarding school type, almost half (48\%) the schools were regular high schools and $38 \%$ were 'multi-track' ('Makif') ones, which in Israel denotes a high school offering several alternative tracks. Vocational and agricultural schools constituted only $11 \%$. As for the subsamples, the religious sector included relatively more 'multi-track' schools, but the 
non-religious sector had more regular schools and thus both types comprised between $84 \%$ and $90 \%$ in both sectors.

\section{Table 2}

\section{Type of Schools Included in the Sample}

\begin{tabular}{lccc}
\hline Type of School & Non-religious Sector & Religious Sector & Total Sample \\
\cline { 1 - 3 } Regular & 49.3 & 42.9 & 48.0 \\
'Multi-track' ('Makif') & 35.1 & 47.6 & 37.8 \\
Vocational & 10.4 & & 8.2 \\
Agricultural & 1.3 & 9.5 & 3.1 \\
Other & 3.9 & & 3.1 \\
\hline Total No. of Schools & $100 \%$ & $100 \%$ & $100 \%$ \\
& $\mathrm{~N}=77$ & $\mathrm{~N}=21$ & $\mathrm{~N}=98$ \\
\hline
\end{tabular}

Level of schools: the vast majority were either upper 3-year schools $(48 \%)$ or sixyear ones $(42 \%)$ with the junior-high ones comprising only $10 \%$ of the sample, most of them non-religious. The religious sector subsample included relatively more six-year schools than the non-religious sector, while the opposite was true concerning upper 3-year schools, reflecting a structural difference between the two sectors.

\section{Table 3}

Level of Schools Included in the Sample

\begin{tabular}{lccc}
\hline \multicolumn{1}{c}{ Level of School } & Non-religious Sector & Religious Sector & Total Sample \\
\hline $\begin{array}{l}\text { Junior High } \\
\text { (Grades 7-9) }\end{array}$ & 11.7 & 4.8 & 10.2 \\
$\begin{array}{l}\text { Upper Three-year } \\
\text { (Grades 10-12) }\end{array}$ & 54.5 & 23.8 & 48.0 \\
$\begin{array}{l}\text { Six-year } \\
\text { (Grades 7-12) }\end{array}$ & 33.8 & 71.4 & 41.8 \\
\hline Total No. of Schools & $100 \%$ & & $100 \%$ \\
& $\mathrm{~N}=77$ & $\mathrm{~N}=21$ & $\begin{array}{c}100 \% \\
\mathrm{~N}=98\end{array}$ \\
\hline
\end{tabular}

Table 4 shows that slightly more than half of the libraries $(51 \%)$ aged more than 20 years, another $27.5 \%$ aged 11 to 20 years and only $21.5 \%$ were younger. The mean and median ages were very similar: both close to 21 years.

Contrary to the findings of the exploratory study, the current full study revealed only slight differences between the two subsamples: the religious sector had slightly more libraries in the 'younger' category (1-10 years) but balanced this by having $2 \%$ more 
libraries in the oldest category of 21 years or more, affecting its median (21.4) to be slightly higher (compared to 20.8 in the non-religious sector) while both means were very close $(20.7$ vs. 20.8).

Table 4

Distribution of Sample According to Library Age (in \%). (Figures in Parenthesis Denote Distribution of School Age

\begin{tabular}{lcrr}
\hline $\begin{array}{c}\text { Age of Library (and } \\
\text { school) (in years) }\end{array}$ & $\begin{array}{c}\text { Non-religious Sector } \\
\text { Library (school) }\end{array}$ & $\begin{array}{r}\text { Religious Sector } \\
\text { Library (school) }\end{array}$ & $\begin{array}{c}\text { Total Sample } \\
\text { Library (school) }\end{array}$ \\
\hline $1-5$ & $6.5(2.6)$ & $14.3(0)$ & $8.2(2.0)$ \\
$6-10$ & $14.3(10.4)$ & $9.5(9.5)$ & $13.3(10.2)$ \\
$11-15$ & $16.9(11.7)$ & $9.5(0)$ & $15.3(9.2)$ \\
$16-20$ & $11.7(7.8)$ & $14.3(9.5)$ & $12.2(8.2)$ \\
21 or more * & $50.6(67.5)$ & $52.4(80.9)$ & $51.0(70.4)$ \\
\hline Total No. of Schools & $100 \%$ & $100 \%$ & $100 \%$ \\
\hline Mean & $\mathrm{N}=77$ & $\mathrm{~N}=21$ & $\mathrm{~N}=98$ \\
SD & $21.1(24.4)$ & $20.7(27.2)$ & $20.8(25.0)$ \\
Median & $10.2(9.2)$ & $10.8(7.4)$ & $10.1(8.9)$ \\
\hline
\end{tabular}

* For calculation purposes, the upper limit was set at 40 .

Comparison of the parenthesized figures which denote the age distribution of the schools themselves reveals that the schools sampled dated older than their libraries, a known and common finding since many schools experience some delay in establishing their library. Thus, over two-thirds of schools (70\%) are 21 years old or older but only $51 \%$ of the libraries are that age, while in all four younger categories ( 20 years and less) the proportions of the schools were lower that those of their libraries.

Schools in the religious sector were relatively older, with $81 \%$ existing 21 years or more vs. only $67.5 \%$ in the non-religious sector. This is possibly because the latter sector is much larger and thus more likely to open new schools with time.

Table 5 clearly shows that schools in the non-religious sector have a much larger student population than those in the religious sector. Relatively small schools of 500 students or less comprise about one-third of the latter sector vs. only $13 \%$ in the nonreligious sector. Eighty-five percent of the religious schools have up to 750 students vs. only $31 \%$ in the non-religious sector. At the other end of the scale, over half the schools in the non-religious sector are attended by more than 1000 students, while only $10 \%$ of schools in the religious sector have a student body of that size. Of course, this difference is also manifested in the measures of central tendency: the mean and median in the non-religious sector almost double those of the religious sector. 


\section{Table 5}

\section{Size of Student Population in High Schools Sampled}

\begin{tabular}{lccc}
\hline \multicolumn{1}{c}{ Student Population } & Non-religious Sector & Religious sector & Total Sample \\
\hline up to 250 & & 9.5 & 2.0 \\
$251-500$ & 13.0 & 23.8 & 15.3 \\
$501-750$ & 18.2 & 52.4 & 25.5 \\
$751-1000$ & 18.2 & 4.8 & 15.3 \\
$1001-1500$ & 28.6 & 9.5 & 24.5 \\
$1501-2000$ & 14.3 & & 11.2 \\
More than 2000* & 7.8 & & 6.1 \\
\hline Total No. of Schools & $100 \%$ & $100 \%$ & $100 \%$ \\
& $\mathrm{~N}=77$ & $\mathrm{~N}=21$ & $\mathrm{~N}=98$ \\
\hline Mean & 1123 & 589 & 1009 \\
SD & $(585)$ & $(285)$ & $(577)$ \\
Median & 1012 & 580 & 867 \\
\hline
\end{tabular}

* For calculation purposes, the upper limit was set at 3000

School size, presumably, had implications on the size of the library's collection, and since schools in the non-religious sector are much larger (as shown in Table 5) their libraries are also fairly large, whether measured in titles or volumes. The upper forty-three percent reported a collection size of over 7500 titles (including $27 \%$ with over 10000 each!) while in the religious sector the figure is $14 \%$. Small collections of up to 2500 titles were reported by $6.5 \%$ in the non-religious sector vs. $19 \%$ in the religious one.

Volume-wise, the picture was similar: an over- 10000 volumes collection was owned by about $47 \%$ of the libraries in the non-religious sector, including $18 \%$ which reported more than 20000 volumes, while only $24 \%$ of the religious schools libraries reported an over10000 collection, with no library exceeding the 20000 mark.

\section{Table 6}

\section{Size of Library Collections in High Schools Sampled}

\begin{tabular}{lcccc}
\hline & \multicolumn{2}{c}{ Titles } & \multicolumn{2}{c}{ Volumes } \\
& $\begin{array}{c}\text { Non-religious } \\
\text { Sector }\end{array}$ & $\begin{array}{c}\text { Religious } \\
\text { Sector }\end{array}$ & $\begin{array}{c}\text { Non-religious } \\
\text { Sector }\end{array}$ & $\begin{array}{c}\text { Religious } \\
\text { Sector }\end{array}$ \\
\hline Mean & 9078 & 5071 & 12159 & 7190 \\
(SD) & $(6795)$ & $(3276)$ & $(7383)$ & $(5088)$ \\
Median & 6737 & 4822 & 9610 & 5625 \\
\hline Total No. of Schools & $\mathrm{N}=77$ & $\mathrm{~N}=21$ & $\mathrm{~N}=77$ & $\mathrm{~N}=21$ \\
\hline
\end{tabular}


At the same time, the proportion of libraries reporting small collections of less than 5000 volumes was 2.6 times greater in the religious sector: about $48 \%$ vs. only $18 \%$ in the non-religious one.

The statistically significant differences between the two sectors regarding collection size are also manifested in the measures of central tendency presented in table 6 . Concerning titles, the ratios between both means was 1.79 and between medians -1.40 . Concerning volumes, the ratio was 1.69 between the means and 1.71 between medians.

In both sectors, the non-fiction was generally much larger than the fiction collection: while only $22 \%$ among the non-religious sector reported a non-fiction collection smaller than 2500 volumes, $48 \%$ of these libraries reported a fiction-collection of such small size. Twenty-six percent reported a non-fiction collection greater than 10000 volumes, but only $6.5 \%$ had a fiction collection of that size.

Paradoxically, the proportion of libraries carrying a very small fiction collection of up to 1000 volumes was 7 times greater than those having a non-fiction collection of that size: $18 \%$ vs. $2.6 \%$.

A similar difference was found in the religious sector : close to $40 \%$ of the libraries had a non-fiction collection of over 5000 volumes, but only $10 \%$ had a fiction collection of that size. About $62 \%$ of the libraries in this sector had a small fiction collection of up to 1000 volumes vs. $24 \%$ having a non-fiction collection of that size.

\section{Table 7}

\section{Size of Non-Fiction and Fiction Collections in High Schools Sampled}

\begin{tabular}{|c|c|c|c|c|}
\hline & \multicolumn{2}{|c|}{ Non-fiction } & \multicolumn{2}{|c|}{ Fiction } \\
\hline & $\begin{array}{l}\text { Non-religious } \\
\text { Sector }\end{array}$ & $\begin{array}{l}\text { Religious } \\
\text { Sector }\end{array}$ & $\begin{array}{l}\text { Non-religious } \\
\text { Sector }\end{array}$ & $\begin{array}{c}\text { Religious } \\
\text { Sector }\end{array}$ \\
\hline Mean & 7854 & 4690 & 4364 & 1821 \\
\hline (SD) & $(6561)$ & (3910) & $(4769)$ & $(2254)$ \\
\hline Median & 5417 & 3750 & 2698 & 822 \\
\hline Total No. of Schools & $\mathrm{N}=77$ & $\mathrm{~N}=21$ & $\mathrm{~N}=77$ & $\mathrm{~N}=21$ \\
\hline
\end{tabular}

These differences are reflected in the measures shown in table 7 . In the non-religious sector the ratio of non-fiction to fiction was 1.8 between means and 2.0 between medians, while in the religious sector the respective ratios were 2.6 and 4.6 .

Comparing sectors, for non-fiction collections the mean and median of the nonreligious sector were 1.67 and 1.44 times higher than in the religious sector, and for fiction collections the respective ratios were 2.4 and 3.3 .

Differences in library size between the two sectors also showed in their 'annual growth', measured by the 'number of volumes added in the previous year'. Over 250 238

Inspiring connections: Learning, libraries \& literacy 
volumes were added by $77 \%$ of the libraries in the non-religious sector, but only by $29 \%$ in the religious one. Small addition of up to 100 volumes were reported by $38 \%$ in the religious sector vs. only $13 \%$ in the non-religious one. The mean addition for the non-religious sector was 745 volumes, 3.6 times higher than the mean in the religious sector (208) and the ratio between the corresponding medians was 3.2 (495 vs. 154).

\section{Application of Censorship in Practice}

The first part of the questionnaire included, besides the 'demographic' questions, several direct questions regarding the type and extent of 'censorship' actually employed in the library. The first question was phrased as follows: "In your library, is there any form of supervision, control or restriction over the content of books added to the collection?". The explicit term 'censorship' was deliberately avoided due to its negative connotation here in colloquial use (concerning theater plays, movies etc.) which was liable to bias the librarians in their response.

Table 8 shows that almost $40 \%$ of the libraries, in both sectors, chose the first response: "always, as a regular and constant routine, regarding every book added to the collection". There was, however, a very significant difference discrepancy between the sectors regarding libraries doing so "frequently, but not always": $43 \%$ in the religious sector vs. only $17 \%$ in the non-religious one, 2.5 times more. Those doing it "seldom" or "never" amounted to $44 \%$ in the non-religious sector vs. only $19 \%$ in the religious one.

\section{Table 8}

\section{Frequency of Exerting 'Censorship' when Acquiring New Books}

\begin{tabular}{lcccc}
\multicolumn{1}{c}{ Religious Sector } & \multicolumn{3}{c}{ Non-Religious Sector } \\
\cline { 2 - 4 } Frequency of 'censorship' & No. & $\%$ & No. & $\%$ \\
Always & 30 & 39.0 & 8 & 38.1 \\
Frequently & 13 & 16.9 & 9 & 42.9 \\
Seldom & 19 & 24.7 & 2 & 9.5 \\
Never & 15 & 19.5 & 2 & 9.5 \\
\hline Total No. of Schools & $\mathrm{N}=77$ & $100 \%$ & $\mathrm{~N}=21$ & $100 \%$ \\
\hline
\end{tabular}

Thus, it can be said that most libraries in both sectors (56\% and $81 \%$ ) applied some form of 'censorship' always or at least frequently. Table 8 as well as the interviewers' personal impressions, indicate that this practice (i.e. exerting some kind of 'censorship') is considered common and legitimate, even positive, certainly nothing to be ashamed of, among the librarians interviewed. One should bear in mind that they could easily have denied any kind of 'censorship' in their library or at least downplayed its frequency, had they considered it an 'unacceptable' practice. 
Table 9 summarizes the answers to the next question: "Who is responsible for this supervision, control, or restriction, and performs it routinely?" In all schools the 'censorship' clearly did not derive from any source outside the school, but was an 'internal censorship', coming from within the school itself. Again, the two sectors differed significantly: while in the non-religious one almost $70 \%$ of the libraries reported that the 'censorial supervision' was done entirely by the librarians, this was the case in only $33 \%$ of the libraries in the religious sector, with the rest reporting that this task was performed either by the head librarian in cooperation with the school principal and/or teachers (48\%) or by the school principal alone (19\%).

\section{Table 9}

\section{Person Responsible for Applying 'Censorship' when Acquiring New Books}

\begin{tabular}{|c|c|c|c|c|}
\hline \multirow{2}{*}{$\begin{array}{c}\underline{\text { Religious }} \\
\underline{\text { Responsible Person }} \\
\end{array}$} & \multicolumn{4}{|c|}{ Non-Religious } \\
\hline & No. & $\underline{\%}$ & No. & $\underline{\%}$ \\
\hline Head Librarian & 43 & 60.6 & 6 & 28.6 \\
\hline Other Librarian(s) & 6 & 8.5 & 1 & 4.8 \\
\hline School Principal & 4 & 5.6 & 4 & 19.0 \\
\hline Teacher(s) & 3 & 4.2 & 0 & 0 \\
\hline $\begin{array}{l}\text { Head Librarian + } \\
\text { School Principal }\end{array}$ & 7 & 9.9 & 8 & 38.1 \\
\hline $\begin{array}{l}\text { Head Librarian }+ \\
\text { Teacher(s) }\end{array}$ & 4 & 5.6 & 1 & 4.8 \\
\hline $\begin{array}{l}\text { Head Librarian }+ \\
\text { Teacher(s) + School } \\
\text { Principal }\end{array}$ & 3 & 4.2 & 1 & 4.8 \\
\hline No Restriction & 1 & 1.4 & 0 & 0 \\
\hline Total No. of Schools & $\mathrm{N}=71$ & $100 \%$ & $\mathrm{~N}=21$ & $100 \%$ \\
\hline Unknown & 6 & & & \\
\hline
\end{tabular}

This may attest to less independence and lower status of librarians in the religious sector schools. On the other hand, it may indicate, at least in some of these schools, a cooperative effort in the process of collection building, to ensure greater conformity to the schools' curriculum and educational goals. None of the librarians interviewed mentioned any external pressure to censor the existing collection or books being acquired and censorship was clearly self-imposed, initiated by the librarians themselves and/or others of the school staff, although many of them were probably unaware that they had been doing so.

To be sure, there seems to be some contradiction between the figure in table 8 , in which about $20 \%$ answered 'never' and the only one library reporting 'no restriction'. One possible explanation is that those librarians probably did not sufficiently notice the close association between the two questions despite their proximity in the questionnaire and the 
same wording used ('supervision' and 'control'). The former question was probably perceived somewhat unfavorably and thus elicited a higher percentage of 'never' answers, while the latter question was positively construed as selection in the process of collection building.

Table 10 summarizes the answers to the question: "Does your library have any rules or guidelines for the practical application of this 'censorship'?”

Most libraries (74\%) in the non-religious sector had no routine guidelines, or even any unwritten instructions or policy regarding the practical application of internal censorship', and only one had a written document. In the religious sector, however, about half the libraries reported having "unwritten routine guidelines" vs. only $25 \%$ in the nonreligious sector, a clear indication of a much greater awareness of the issue of 'undesirable books' in the former sector, and higher measure of openness and permissiveness in the latter one.

Table 10

Existence of Rules or Guidelines for the Practical Application of 'Censorship'

\begin{tabular}{lllll}
\hline \multicolumn{1}{c}{ Religious } & \multicolumn{4}{c}{ Non-Religious } \\
& No. & $\frac{1}{2}$ & No. & $\%$ \\
\hline Written Routine Guidelines & 1 & 1.3 & 0 & 0 \\
Unwritten Routine Guidelines & 19 & 24.7 & 10 & 47.6 \\
No Routine Guidelines at all & 57 & 74.0 & 11 & 52.4 \\
\hline Total No. of Schools & $\mathrm{N}=77$ & $100 \%$ & $\mathrm{~N}=10$ & $100 \%$ \\
\hline
\end{tabular}

How can one reconcile the high percentage of libraries with no guidelines with the above findings (Table 8 ) that between $56 \%$ and $81 \%$ of the libraries sampled actually apply, always or frequently, some extent of 'censorship' in the continuous process of collection building? Apparently, most libraries solve the problems intuitively, judging each case in itself, and there have not been any controversial cases which could have drawn the public and media attention and obliged the libraries to form some code of relevant rules and guidelines.

The last question in the first part of the questionnaire specified 22 topical categories of books and the librarian was asked to check those which "his library prefers, in principle, to exclude from its collection, i.e. 'undesirable' items". Due to its exceptional size and the quantity of tables and analyses based on the answers to this complex question, it had to be left for a separate publication.

However, several interesting findings should be briefly mentioned:

1. 'Hard' pornography topped the 'undesirable' list in both sectors, being rejected by $100 \%$ of the libraries in the religious sector and $94 \%$ in the non-religious sector. 
2. Racism, advocating of drug use and 'hard' violence were next on the list, being rejected by 78 to 75 percent in the non-religious sector and by higher rates $(76 \%$, $86 \%$ and $91 \%$ correspondingly) in the religious sector.

3. Books with a positive approach to mystical closed and bizarre sects ('Devil Worship' etc.) denying the Holocaust (i.e. the mass murder of 6 million Jews by Nazi Germany during World War II) or comparing Zionism to racism were also rejected by over half the libraries in the non-religious sector $(57 \%, 55 \%$ and $52 \%)$ and by about two-thirds in the religious sector $67 \%, 62 \%$ and $67 \%$ correspondingly).

4. Expectedly, the prominent difference between the two sectors emerged again regarding books whose content "encourages sexual permissiveness", includes 'soft' pornography or "degrades the Jewish religion, beliefs, commands, principles or values". Such books would be rejected by the vast majority of the libraries in the religious sector $(95 \%, 81 \%$ and $88 \%)$ but only by about half or less of the libraries in the non-religious one $(45 \%, 44 \%$ and $53 \%$ correspond-ingly).

\section{Collection Balance}

The second part of the questionnaire included four lists of specific book titles (25 to 30 in each list) to be checked against the library catalog, in order to verify the reliability of the librarians' answers to the first part of the questionnaire, using the 'triangulation' technique, as well as to detect possible political or ideological 'biases' in the collections. The four lists included Hebrew titles dealing with: (1) violence, explicit eroticism, etc. (2) rightwing orientation, (3) left-wing orientation, (4) Judaism, Jewish classics, repentance, etc. Proportions of titles held, for each of the four lists, were calculated for each library, as well as measures of central tendency and variability for each of the sectors, as shown in Table 11.

Table 11

\section{Proportions of Titles Owned from Each Topical Group (in \%)}

\begin{tabular}{|c|c|c|c|c|}
\hline \multirow{2}{*}{$\begin{array}{r}\text { Religious } \\
\text { Topic of Title List }\end{array}$} & \multicolumn{4}{|c|}{ Non-Religious } \\
\hline & Mean (SD) & Median & Mean (SD) & $\underline{\text { Median }}$ \\
\hline $\begin{array}{l}\text { Violence, soft } \\
\text { pornography, etc. }\end{array}$ & $\begin{array}{l}55 \% \\
(18)\end{array}$ & $57 \%$ & $\begin{array}{l}17 \% \\
(15)\end{array}$ & $17 \%$ \\
\hline Right-wing orientation * & $\begin{array}{l}23 \% \\
(15)\end{array}$ & $20 \%$ & $\begin{array}{c}20 \% \\
(12.5)\end{array}$ & $16 \%$ \\
\hline Left-wing orientation * & $\begin{array}{l}36 \% \\
(20)\end{array}$ & $32 \%$ & $\begin{array}{l}11 \% \\
(8.5)\end{array}$ & $12 \%$ \\
\hline $\begin{array}{l}\text { Judaism, Jewish classics, } \\
\text { repentance, etc. }\end{array}$ & $\begin{array}{l}27 \% \\
(11)\end{array}$ & $28 \%$ & $\begin{array}{l}61 \% \\
(16)\end{array}$ & $60 \%$ \\
\hline Total No. of Schools & $\mathrm{N}=77$ & $\mathrm{~N}=77$ & $\mathrm{~N}=21$ & $\mathrm{~N}=21$ \\
\hline
\end{tabular}

* See Appendix. 
Analysis of the average proportions owned from each of the four lists revealed considerable differences between the two sectors:

1. The 'non-religious' group had over three times the percentage from the first list (explicit violence and pornography) compared to the 'religious' sector group. This corroborates the abovementioned finding, based on the answers to the 22 topical categories, of much greater permissiveness in the non-religious sector regarding the content of titles to be added to the collection.

2. The fourth list ('Judaism') revealed a reverse situation, meaning that the nonreligious sector owned on the average less than half the percentage owned by libraries in the religious sector : $27 \%$ vs. $61 \%$ (or $28 \%$ vs. $60 \%$ if medians are compared). The large difference regarding the 'Judaism' list is, of course, explained by the very nature, orientation and ideological foundations of both sectors, and the much greater emphasis placed by the religious sector on Judaism, Jewish classics, national and religious values, etc.

3. Interestingly, the religious sector group had lower percentages not only from the 'left-wing' list (11\%-12\% vs. over 30\% in the non-religious sector) as expected, but surprisingly also from the 'right-wing' list (16\%-20\%) compared to the 'nonreligious' sector $(20 \%-23 \%)$ a fact explained by their relatively smaller collections, as shown above (Table 6 and 7).

4. Nevertheless, as shown by a within-group analysis, when each sector is compared to itself, the religious sector group had relatively more titles from the 'right' list compared to the 'left' one ( $20 \%-16 \%$ vs. $11 \%-12 \%)$, while the non-religious group had considerably more titles from the 'left' list: $36 \%$ vs. $23 \%$ (or $32 \%$ vs. $20 \%$ if medians are compared). All differences were statistically significant at $\mathrm{p}<0.01$.

The abovementioned bias also appears when comparing means and medians of both sectors, i.e. a between-groups analysis. While for the 'right-wing' list the ratio between means is only $1.15(23 / 20)$ and between medians only $1.25(20 / 16)$, in favor of the nonreligious sector, for the 'left-wing' list the ratios in favor of that sector are significantly higher: $3.27(30 / 11)$ between means and $2.67(32 / 12)$ between medians.

The difference between the two sectors concerning the proportion of 'right' and 'left' titles owned by each is also illustrated by another measure, based on the following ratio:

Average group percentage of 'left-wing' titles held by libraries of sector $x$

Average group percentage of 'right-wing' titles held by libraries of sector $x$

Alternately, it can also be measured in an inverted manner, i.e. 'right-wing' / 'leftwing' titles.

Table 12 presents the ratios for each sector, calculated on the basis of group means and medians, again indicating the statistically-significant difference and 'collection bias' of each sector. 
Table 12

Ratio of 'Left' List / 'Right' List Group Percentages in Both Sectors *

\begin{tabular}{lcc}
\hline & Non-religious sector & $\underline{\text { Religious sector }}$ \\
\hline & Ratio of 'Left' list / 'Right' list holdings \\
Between Group Means & 1.56 & 0.55 \\
Between Group Medians & 1.60 & 0.75 \\
Between Group Means & Ratio of 'Right' list / 'Left' list holdings \\
Between Group Medians & 0.64 & 1.82 \\
\hline
\end{tabular}

*See Appendix.

This finding is explained by the different political and ideological orientation of library and school staff employed in each sector.

Schwarzwald (1990: 91-111) reviewed a long list of studies which indicate clearly a much stronger Jewish identity, combined with deeper religious and national elements, among students of the religious sector, compared to those in the non-religious sector. A major reason is presumably the considerable differences in ideology and attitudes between teachers in both sectors, as revealed in former studies (such as Bartal a.o. 1978). Analyses of elections and public opinion poles by Israeli sociologists and political scientists have long established that the religious sector in Israel is much more 'right-wing' orientated than the non-religious one.

Two points, however, should not be overlooked:

1. The great variability within each of the two groups, as indicated by the relatively high measures of standard deviations, denoting significant individual differences between libraries in the same sector.

2. Neither sector totally bans titles identified with the 'opposite' sector. On the average the non-religious sector owned $23 \%$ (or $20 \%$ if the median is used) of the titles included in the 'rightist' list, and the religious sector owned $11 \%$ (or 12\%) of the 'leftist' titles, probably due to its smaller collections.

\section{CONCLUSIONS}

1. Most libraries in the sample actually apply some form of 'censorship' to books added to their collection, but this 'censorship' is internal rather than originating in sources outside the school.

2. Most libraries had no kind of written or unwritten document which specified rules or guidelines for applying this abovementioned 'censorship'. 
3. School libraries in the religious sector differ from those in the non-religious one in their smaller collections, much fewer fiction titles containing violence, eroticism, explicit sex, etc. and many more non-fiction titles on Jewish topics.

4. The libraries in the religious sector had less titles from both the 'right-wing' and 'leftwing' title lists, compared to the non-religious sector, but the former sector had relatively more 'right-wing' titles while the non-religious sector had more 'left-wing' titles.

5. Nonetheless, caution is warranted since these conclusions are based on a sample of about 100 libraries (20\% of the population) and on a relatively small and limited sample list of selected titles. Further research is needed, using another sample of high school libraries, and different lists of titles representing the four topic areas mentioned above.

\section{REFERENCES}

Arian, A. (1998). The second republic; Politics in Israel. Chatham, Chatham House Publishing.

Bar-Tal, D. (1978). High school teachers attitudes towards questions of education, nation and society. Tel-Aviv, Tel-Aviv University School of Education.

Boardman, Edna (1993). Censorship and intellectual freedom in the schools. Book Report, 11 (5), 14-27.

Burress, L. A., Jr. (1967). The role of english teachers and librarians in book selection. p.114. (ERIC Document Reproduction Service No. ED 250 681).

Foerstel, H. N. (1994). Banned in the USA: Reference guide to book censorship in schools and public libraries. Westport, CT, Greenwood Press.

Hansen, Eileen. (1987). Censorship in schools: studies and surveys. School Library Journal, 34 (1), 123-125.

Hopkins, D. M. (1989). Toward a conceptual model of factors influencing the outcome of challenges to library materials in school settings. Library and Information Science Research, $11(3), 247-271$.

Hopkins, D. M. (1993). A conceptual model of factors influencing the outcome of challenges to library materials in secondary settings. Library Quarterly, 63 (1), 40-72.

Hopkins, D. M. (1995). Challenges to library materials from principals in United States secondary schools - A "victory" of sorts. School Library Worldwide, 1 (2), 8-29.

Isaac, R. J. (1976). Israel divided; Ideological politics in the Jewish state. Baltimore and London: John Hopkins University Press.

Martorelli, D. (1982). When the censor calls ... how will you answer. Instructor and Teacher, 91, 92.

Oboler, E. M. (1980). The controversy surrounding values education. School Library Journal, 27 (2), 115-117.

Rolef, S. H. (1993). Political dictionary of the state of Israel. Jerusalem, The Jerusalem Publishing House.

Schrader, A. M. (1996). Censorproofing school library collections: the fallacy and futility. School Libraries Worldwide, 2 (1), 71-94.

Schwarzwald, J. (1990). A research perspective on religious public education in Israel. Ramat-Gan, Bar-Ilan University Press. (in Hebrew).

Serebnik, J. (1982). Self-censorship by librarians: an analysis of checklist-based research. Drexel Library Quarterly, 18 (1), 35-56. 
Symons, A. K., \& Harmon, C. (1995). Protecting the right to read: A how-to-do-it manual for school and public librarians. p.211. (ERIC Document Reproduction Service No. ED 391 529).

Woods, L. B. (1989). Bibliography on censorship and intellectual freedom, 1976-88. p.7. (ERIC Document Reproduction Service No. ED 314 054).

Woods, L. B. \& Salvatore, L. (1981). Self-censorship in collection development by high school library media specialists. School Media Quarterly, 9 (2), 102-108. 


\section{APPENDIX}

Definitions of right-wing and left-wing in current Israeli politics and party system may differ to some extent from common definitions found in political science textbooks. Originally, Israeli right-wing parties represented what is considered a liberal position economically, combining a welfare state approach with greater emphasis on free enterprise, and a conservative position ideologically, putting more emphasis on Jewish tradition and heritage. However, traditional economic labels became increasingly absurd when the rightwing parties drew their preponderant voting strength from the poorest of the Israeli proletariat, notably those emigrated to Israel from Arab countries (in the Middle-East and North-Africa) while the strength of the left-wing (usually socialist labor parties) came from middle - and upper-class districts. Concerning foreign policy, one may say that, generally speaking, Israeli right-wing parties believe that Arab countries surrounding Israel have not yet given up their old plan of destroying the Jewish state, but are trying to do it gradually in stages rather than in one blow. Consequently, affected also by the Holocaust trauma, the right-wing parties display a more 'hawkish' stand towards the Arabs, holding that Israel's security and sheer existence dictate minimum of territorial compromise and concessions, which might only serve as a jumping-board to a future destruction of Israel. Usually, rightwing ideology has been relatively more nationalistic, with more understanding of, sensitivity to, and emphasis on the Jewish roots and heritage of the state, being expressed in the educational system and in public life (Isaac, 1976; Rolef, 1993; Arian, 1998). 